ARTICLE

DOI: $10.1038 / \mathrm{s} 41467-018-04625-7$

\title{
Enhanced ocean-atmosphere carbon partitioning via the carbonate counter pump during the last deglacial
}

Stéphanie Duchamp-Alphonse ${ }^{1}$, Giuseppe Siani ${ }^{1}$, Elisabeth Michel ${ }^{2}$, Luc Beaufort ${ }^{3}$, Yves Gally ${ }^{3} \&$ Samuel L. Jaccard (10 ${ }^{4}$

Several synergistic mechanisms were likely involved in the last deglacial atmospheric $p \mathrm{CO}_{2}$ rise. Leading hypotheses invoke a release of deep-ocean carbon through enhanced convection in the Southern Ocean (SO) and concomitant decreased efficiency of the global softtissue pump (STP). However, the temporal evolution of both the STP and the carbonate counter pump (CCP) remains unclear, thus preventing the evaluation of their contributions to the $\mathrm{pCO}_{2}$ rise. Here we present sedimentary coccolith records combined with export production reconstructions from the Subantarctic Pacific to document the leverage the SO biological carbon pump (BCP) has imposed on deglacial $p \mathrm{CO}_{2}$. Our data suggest a weakening of $\mathrm{BCP}$ during the phases of carbon outgassing, due in part to an increased $\mathrm{CCP}$ along with higher surface ocean fertility and elevated $\left[\mathrm{CO}_{2 a q}\right]$. We propose that reduced $\mathrm{BCP}$ efficiency combined with enhanced SO ventilation played a major role in propelling the Earth out of the last ice age.

\footnotetext{
${ }^{1}$ GEOPS, Universities of Paris Sud and Paris-Saclay, CNRS, 91405 Orsay, France. ${ }^{2}$ LSCE/IPSL Laboratoire des Sciences du Climat et de I'Environnement, CEACNRS-UVSQ, 91198 Gif-sur-Yvette, France. ${ }^{3}$ Aix Marseille Univ, CNRS, IRD, INRA, Coll France, CEREGE, Aix-en-Provence, France. ${ }^{4}$ Institute of Geological Sciences and Oeschger Center for Climate Change Research, University of Bern, 3012 Bern, Switzerland. Correspondence and requests for materials should be addressed to S.D.-A. (email: stephanie.duchamp@u-psud.fr)
} 
$\mathrm{T}$ he Southern Ocean (SO) is a key part of the global overturning circulation as it witnesses the outcropping of carbon- and nutrient-rich Circumpolar Deep Water $(\mathrm{CDW})$ in the Antarctic Zone (AZ), as a result of wind-driven (Ekman) upwelling ${ }^{1}$. A portion of these upwelled waters flow southwards to feed the abyssal circuit to form Antarctic Bottom Water (AABW), while the remainder flows to the North to feed Subantarctic Surface Waters (SSW) that mix with warm subtropical waters to form Antarctic Intermediate Waters (AAIW) and Subantarctic Mode Waters (SAMW), the mid-depth oceanic circuit that supplies nutrients to the low-latitude thermocline $e^{1,2}$. The STP, that is the net downward flux of carbon associated with organic matter export, counteracts carbon evasion to the atmosphere, as a fraction of the photosynthetic biomass that fixes dissolved inorganic carbon (DIC) in the sunlit ocean is exported and remineralized in the ocean interior. However, owing to iron $(\mathrm{Fe})$ limitation on phytoplankton growth ${ }^{3,4}$, the pre-industrial SO STP was unable to fully compensate the $\mathrm{CO}_{2}$ outgassing and this area represented one of the main oceanic sources of natural $\mathrm{CO}_{2}$ to the atmosphere ${ }^{5}$.

During the last ice age, the deep circuit was probably more isolated from the atmosphere due to increased sea-ice coverage ${ }^{6}$ and increased stratification ${ }^{7,8}$. Meanwhile the STP, fueled by enhanced deposition of Fe-bearing dust that favored a more complete macronutrient uptake by phytoplankton, might have been more efficient $t^{3,9,10}$. Therefore, reduced rates of vertical exchange combined with a more efficient STP promoted the storage of $\mathrm{CO}_{2}$ in the ocean abyss, thereby contributing to lower atmospheric $\mathrm{CO}_{2}{ }^{11,12}$.

The collapse of vertical $\Delta^{14} \mathrm{C}$ and $\delta^{13} \mathrm{C}$ gradients in the SO suggests that more vigorous deep and mid-depth circulations would have reconnected the deep carbon reservoir to the surface during Heinrich Stadial 1 (HS1, 17.5-14.7 kyr BP) and the Younger Dryas (YD, 12.8-11.5 kyr BP), thus promoting the transfer of respired carbon to the surface ocean and the atmosphere ${ }^{13,14}$. These observations have been corroborated by sedimentary geochemical data suggesting that surface waters of the Subantarctic Atlantic and the Eastern Equatorial Pacific (EEP), which derive from water upwelled in the SO, became a substantial source of $\mathrm{CO}_{2}$ during the last deglaciation ${ }^{15}$.

Surprisingly, little is known about deglacial export production and STP patterns in the Subantarctic Zone (SAZ) outside the Atlantic sector. The weakening of the global STP efficiency has been documented during the early deglaciation $(\sim 17.5-\sim 14 \mathrm{kyr}$ BP) using a global compilation of $\delta^{15} \mathrm{~N}$ measurements and oxygenation proxies ${ }^{16}$. Millennial-scale export production reconstructions based on organic (TOC, biomarkers) and inorganic $\left(\mathrm{SiO}_{2}, \mathrm{CaCO}_{3}\right.$, bioBa $)$ proxies ${ }^{9,10,17-21}$ provide insights into oceanic nutrient dynamics, ventilation changes, and export of particulate carbon across the deglaciation. However, these records remain sparse and mainly come from South Atlantic cores located downwind of Patagonia, the most prominent dust source region to the $\mathrm{SO}^{22}$. While they provide valuable case studies for testing the "Fe-hypothesis"3, these records are not necessarily representative of the entire SO. Particularly, the comparison with South Pacific and Indian Oceans is not straightforward because hydrothermal and sedimentary Fe sources may play an important role in modulating productivity in these sectors ${ }^{23}$.

Besides, these reconstructions neither document the contribution of specific phytoplankton groups, nor their respective leverage on the BCP strength. The sedimentary burial of biogenic opal and carbonate, often thought to reflect diatom and coccolithophore export production respectively, could be affected by changes in zooplankton abundance, grazing pressure, and/or changes in the degree of remineralization processes. More importantly, these reconstructions largely ignore the relative contribution of the $\mathrm{CCP}$, despite its fundamental role in the marine carbon cycle ${ }^{24}$. The production of particulate inorganic carbon (PIC) by calcifying plankton in the sunlit ocean and its eventual dissolution in the subsurface engenders a surface-todepth alkalinity gradient, causing $\mathrm{CO}_{2}$ to be released back to the atmosphere ${ }^{24}$. As such, the CCP acts to partially offset the air-sea partitioning of carbon associated with the STP.

Therefore, it is crucial to overcome these important shortcomings by focusing on the production pattern of specific phytoplankton groups from a broad range of locations within the SAZ and evaluating their impact on the carbon cycle. Coccolithophores are relevant for addressing this outstanding issue. This single-celled phytoplankton group has unique effects on the oceanic carbon cycle in that it uses DIC for both photosynthesis and calcification and accounts for a significant proportion of the global marine export production ${ }^{25}$. Hence, coccolithophores contribute to both the STP and CCP and impact the strength of the BCP since modifications in calcification patterns related to changes in surface water chemistry modulate the POC:PIC ratio of sinking biogenic material with consequences for the air-sea partitioning of carbon ${ }^{26-28}$.

Here, we explore the deglacial calcification pattern of coccolithophores, particularly the Noëlaerhabdaceae family, in a welldated sediment core $^{14}$, retrieved from the Chilean margin (MD07-3088; $46.1^{\circ} \mathrm{S}, 75.7^{\circ} \mathrm{W}, 1536 \mathrm{~m}$ water depth), at the transition of AAIW and the Pacific deep water (PDW) ${ }^{2}$ (Fig. 1 and Methods). This site is located within the Antarctic Circumpolar Current (ACC) under the direct influence of the northward transport of nutrient rich-SSW ${ }^{2}$ and relatively far from the main dust sources today, but likely also in the past ${ }^{22}$. As such, this core represents a suitable archive to document the leverage SO upwelling and associated changes in surface water chemistry might have exerted on SAZ coccolithophore productivity. We complement these observations with planktonic foraminifera records to provide a complete representation related to the integrated PIC accumulation and compare these data with reconstructed past changes in the buried POC:PIC ratio, suggested to reflect the C-rain ratio. As such, we qualitatively document the relative contribution of STP and CCP to the deglacial rise in atmospheric $\mathrm{CO}_{2}$ at a decadal timescale. Our study highlights that changes in biological export production in high southern latitudes operated synergistically with physical mechanisms thereby enhancing the transfer of carbon from the ocean to the atmosphere during the last deglacial. The reinvigoration of the SO vertical mixing contributed to the release of respired carbon and regenerated nutrients to the SAZ that promoted planktonic calcification, thereby increasing the CCP, and concomitantly weakening the BCP.

\section{Results and discussion}

Increase in SSW fertility and $\left[\mathrm{CO}_{2 \mathrm{aq}}\right]$ during SO upwelling. In Fig. 2, we present coccolith abundance and mass (Fig. 2a, c, d, i) from sediment core MD07-3088 (Methods) that are compared to $\Delta \Delta^{14} \mathrm{C}$ and $\Delta \delta^{13} \mathrm{C}$ reconstructions from the same core ${ }^{14}$ (Fig. 2f, g), coccolith abundances from the SE Pacific ${ }^{29}$ (ODP 1233, Fig. 2b; Methods and Supplementary Fig. 1), biogenic opal flux from the South Atlantic ${ }^{30}$ (TN057-13-4PC, Fig. 2h), $\delta^{11} \mathrm{~B}$-based $\Delta p_{\mathrm{CO}_{2}}$ from the EEP ${ }^{15}$ (ODP 1238, Fig. 2j; Methods; Supplementary Fig. 1), and local summer SST estimates ${ }^{14,31}$ (Fig. 2e), to better understand their relationships to productivity and ocean circulation patterns on a regional scale (Figs. 1 and 2). Coccolithophore calcification patterns are not affected by diagenetic alteration, with no evidence of coccolith dissolution (Methods and Supplementary Fig. 2). Noëlaerhabdaceae coccolith abundance features three distinct deglacial peaks (18.6-18.2, 17.7-16.2, 

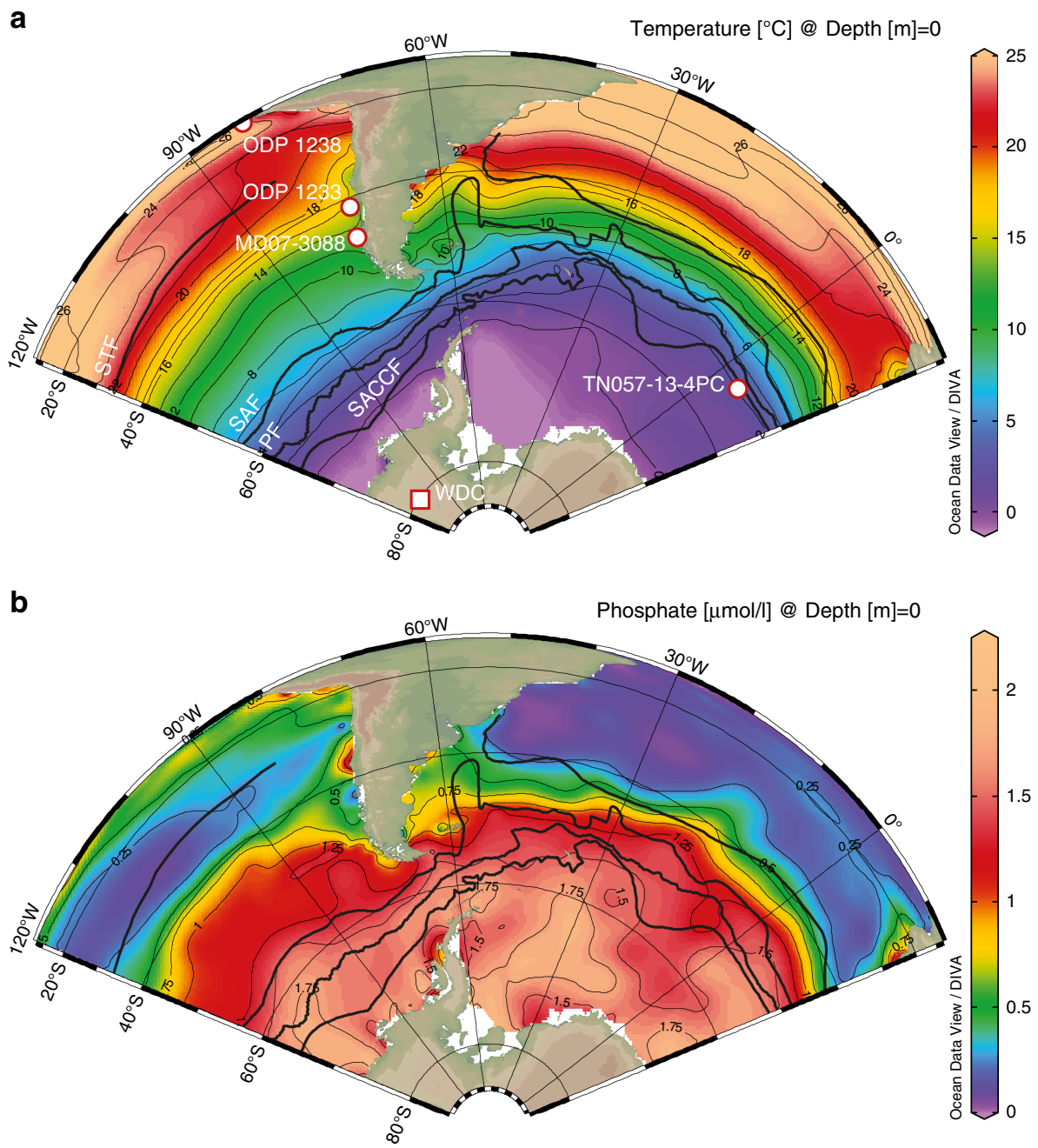

Fig. 1 Location of sites and modern ocean surface temperature and phosphate concentrations. Temperature (a) and phosphate (b) concentration fields are plotted with the Ocean Data View (ODV) software ${ }^{68}$ with WOA09 ${ }^{69}$. Solid black lines represent the: Subtropical (STF), Subantarctic (SAF), Polar (PF) and Subantarctic Circumpolar Current (SACCF) Fronts ${ }^{70}$. The Polar Frontal and Subantarctic Zones are the regions between the PF and SAF, and between the SAF and the STF respectively. a Solid white circles symbolize the geographic location of sediment cores MD07-3088 (46.1 $\left.{ }^{\circ} \mathrm{S}, 75.7^{\circ} \mathrm{W}, 1536 \mathrm{~m}\right), \mathrm{TNO}^{2} \mathrm{57}-13-$ $4 \mathrm{PC}^{30}\left(53.2^{\circ} \mathrm{S}, 5.1^{\circ} \mathrm{E}, 2850 \mathrm{~m}\right)$, and sites ODP $1233^{29}\left(41.0^{\circ} \mathrm{S}, 74.4^{\circ} \mathrm{W}, 838 \mathrm{~m}\right)$ and $1238^{15}\left(1.5^{\circ} \mathrm{S}, 82.5^{\circ} \mathrm{W}, 2203 \mathrm{~m}\right)$. The solid white square highlights the West Antarctic Ice Sheet Divide ice core ${ }^{56}$ (WDC, $79.5^{\circ} \mathrm{S}, 112.1^{\circ} \mathrm{W}, 1766 \mathrm{~m}$ above sea level)

and 12.8-11.1 ka BP), with highest abundances reported for HS1 and the YD (Fig. 2a). Within Subantarctic ecosystems located away from the main dust sources, phytoplankton growth is typically modulated by the supply of dissolved phosphate $\left(\mathrm{PO}_{4}{ }^{3-}\right)$ and nitrate $\left(\mathrm{NO}_{3}^{-}\right)$via $\mathrm{SO}$ upwelling today ${ }^{32}$ but also in the past $^{33,34}$. This is particularly the case for the Chilean margin, where river runoff ${ }^{35}$ and glacier erosion ${ }^{36}$ provide additional sources of micronutrients alleviating the limitation $\mathrm{Fe}$ is imposing on phytoplankton growth in the open $\mathrm{SO}^{34}$. Besides, macronutrient concentrations within the SSW were not perennially high $^{37}$. Therefore, the most reasonable explanation is that coccolith abundance primarily reflects the phytoplankton response to macronutrient supply. This assumption is corroborated by concomitant higher abundances of $H$. carteri and to a lesser degree $C$. leptoporus that have an affinity for meso- to eutrophic conditions in the SE Pacific ${ }^{38}$ (Fig. 2c, d). Besides, the structure of this record closely resembles those of $\Delta \Delta^{14} \mathrm{C}$ and $\Delta \delta^{13} \mathrm{C}$ reconstructions ${ }^{14}$ that reflect increased rates of vertical mixing, thus supporting the notion that upper ocean productivity at site MD07-3088 was directly modulated by regional ocean circulation changes. Furthermore, the downcore coccolithophore export productivity record mimics coccolith abundances in the northern part of the
$\mathrm{SAZ}^{29}$ as well as opal fluxes in the $\mathrm{AZ}$ at sites influenced by similar processes ${ }^{30}$. This suggests that the inferred changes in productivity were neither limited to a specific phytoplankton group nor a specific area, but rather highlight a regional sensitivity of phytoplankton growth to ocean circulation and nutrient supply from below.

The second outstanding feature of the micropalaeontological records relates to the $\sim 50 \%$ distinct increases in the mean Noëlaerhabdaceae coccolith mass (Fig. 2i), coincident with decreasing local $\Delta \Delta^{14} \mathrm{C}$ and $\Delta \delta^{13} \mathrm{C}$ values (Fig. $2 \mathrm{f}, \mathrm{g}$ ) ${ }^{14}$, as well as with increasing surface water $\delta^{11} \mathrm{~B}$-based $\Delta p_{\mathrm{CO}_{2}}$ values in the $\mathrm{EEP}^{15}$ (Fig. 2j; Methods; Supplementary Fig. 1). Numerous studies related coccolith mass to the degree of coccolith calcification in Pleistocene and recent sediments ${ }^{39-41}$. Indeed, variations in coccolith mass can, under some circumstances, reflect variations in the thickness of an individual coccolith, and therefore relates to the calcite quota of a given cell ${ }^{27}$. However, changes in coccolith mass may additionally be driven by changes in coccolith area associated to changes in cell sizes ${ }^{27,28,42}$ and as such coccolith mass must be size-normalized to represent the degree of coccolith calcification ${ }^{27,28}$. At site MD07-3088, we focus on changes that affected all narrowly restricted size classes within 


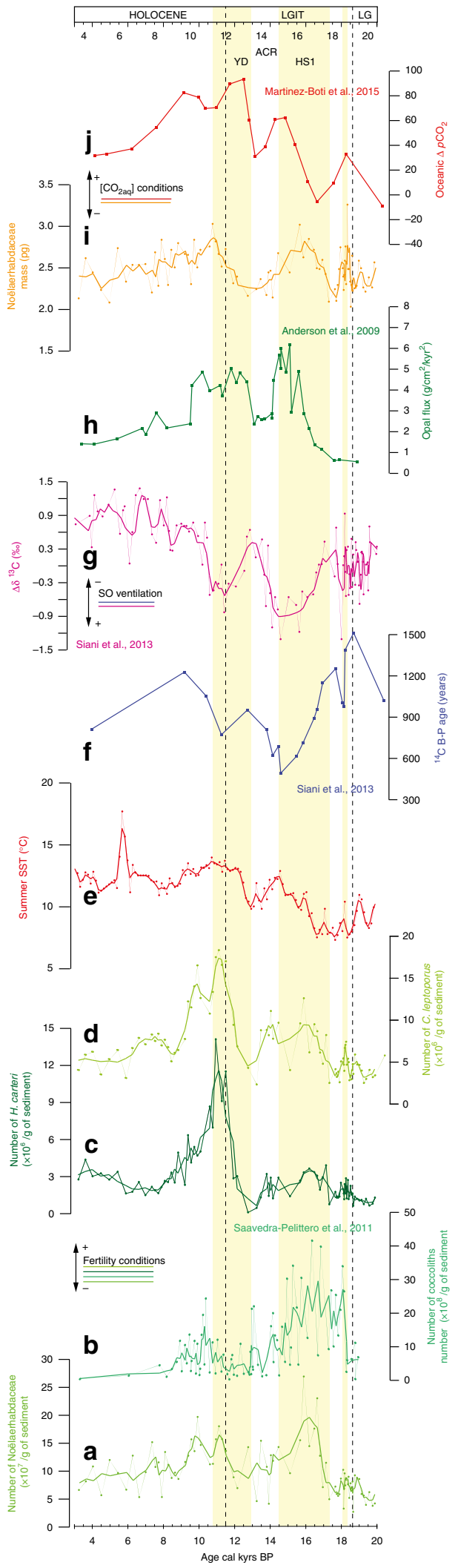

the Noëlaerhabdaceae family ${ }^{43}$ (Supplementary Fig. 2). We find that changes in coccolith mass typically reflect changes in coccolith thickness (Fig. 3), suggesting that they document changes in the coccosphere calcite quota. Our assumptions are further corroborated by the clear positive relationship that exists
Fig. 2 Southern Ocean productivity and circulation patterns during the last deglaciation. a, c, d Number of Noëlaerhabdaceae, $H$. carteri and $C$. leptoporus at site MD07-3088 (/g of sediment), with an error bar of $\pm 1 \%$. b Number of coccoliths at site ODP 1233 (/g of sediment) ${ }^{29}$. e Summer sea surface temperatures $\left(\mathrm{SST},{ }^{\circ} \mathrm{C}\right)$ using the Modern Analogue

Technique ${ }^{14,31} \cdot \mathbf{f}^{14} \mathrm{C}$ age difference between paired benthic and planktonic foraminifera $\left({ }^{14} \mathrm{C} B-P\right)^{14} \cdot \mathbf{g} \Delta \delta^{13} \mathrm{C}=\delta^{13} \mathrm{C}_{\mathrm{G}}$. bulloides $-\delta^{13} \mathrm{C}_{\mathrm{C}}$ wuellerstorf ${ }^{14}$. $\mathbf{h}$ Opal fluxes at TN057-13-4PC ${ }^{30}$. i Noëlaerhabdaceae mass (pg) at site MD07-3088 with an error bar of $\pm 3 \%$. j Surface ocean $\Delta p_{\mathrm{CO}_{2}}$ reconstruction for ODP $1238^{15}$. LG and LGIT are for Late Glacial and Last Glacial-Interglacial Transition, respectively. Smoothed curves (thick lines of $\mathbf{a}-\mathbf{e}, \mathbf{g}$, and $\mathbf{i}$ ) use a three-point moving average. Yellow shading marks periods of enhanced deep-water ventilation and resumption of SO upwelling during the last deglaciation, in conjunction with higher ocean surface fertility, $\left[\mathrm{CO}_{2 \mathrm{aq}}\right]$, and sometimes increased SST conditions

between coccolith mass and the size normalized thickness index "SN"27,44 (Methods) $\left(r^{2}=0.73\right)$ as well as the coccolith aspect ratio "AR $\mathrm{L}_{\mathrm{L}}$ "28 (Methods) $\left(r^{2}=0.63\right)$ (Fig. 3), which both document the degree of Noëlaerhabdaceae coccolith calcification.

Batch culture experiments provided conflicting responses related to coccolithophore calcification rates with studies reporting both depressed ${ }^{45,46}$ or elevated ${ }^{47}$ calcification under $^{-1}$ high $\left[\mathrm{CO}_{2 \mathrm{aq}}\right]$. However, in the geological record-when general selection for growth strategies ${ }^{28}$ and phenotypic plasticity naturally occurred and regulated the carbon acquisition within the cell ${ }^{48}$-more heavily calcified coccoliths were systematically associated with increased atmospheric $\mathrm{pCO}_{2}{ }^{27,28,49,50}$. Indeed, high $p \mathrm{CO}_{2}$ favors intracellular competitive reallocation of dissolved bicarbonate $\left(\mathrm{HCO}_{3}{ }^{-}\right)$from the site of photosynthesis (chloroplast) to the site of calcification (coccolith vesicle) ${ }^{48}$. Such processes may be relevant in coastal ecosystems such as the Chilean margin, where highly calcified E. huxleyi morphotypes thrive under low-pH sea-surface conditions ${ }^{39}$. Therefore, it is most likely that more heavily calcified coccoliths reported from site MD07-3088 at times when the upwelling of $\mathrm{CO}_{2}$-rich deep waters increased, reflect increasing surface $\left[\mathrm{CO}_{2 \mathrm{aq}}\right]$ and highlight the equatorward advection of SSW together with AAIW/SAMW, thus supporting the mechanisms behind upper-ocean acidification previously documented in the SAZ and the EEP during these time intervals ${ }^{15}$. The $50 \%$ increase in Noëlaerhabdaceae mass observed both during $\mathrm{HS} 1$ and $\mathrm{YD}$ occurred at times of $\sim 2-3 \mu \mathrm{mol} / \mathrm{L}$ rises in SSW $\left[\mathrm{CO}_{2 \mathrm{aq}}\right]$ in the $\mathrm{SAZ}^{15}$, which is in the exact same order of magnitude than the coccolith mass and $\left[\mathrm{CO}_{2 \mathrm{aq}}\right]$ increases $(50 \%, \sim 3 \mu \mathrm{mol} / \mathrm{L}$ respectively) previously documented for the penultimate deglaciation within the southernmost Pacific ${ }^{28}$. We cannot exclude that increased temperatures during major upwelling phases $\left(\sim+4{ }^{\circ} \mathrm{C}\right.$ during $\mathrm{HS} 1$, and $\sim+3{ }^{\circ} \mathrm{C}$ during $\left.\mathrm{YD}^{14,31}\right)$, may have partially contributed in promoting coccolith production and calcification ${ }^{28,51}$, but warming was not always in phase with the coccolith patterns, and may thus be of secondary importance (Fig. 2).

Reduced BCP due to increased CCP during SO upwelling. Sedimentary bromine $(\mathrm{Br})$ and calcium $(\mathrm{Ca})$ have been shown to be associated with biogenic organic carbon and carbonate in marine sediment records, respectively. $\mathrm{Br}$ is primarily associated with marine organic matter ${ }^{52}$ as it is directly involved in the marine biological cycle and in non-biological reactions in the water-column that implicate marine organic matter ${ }^{53}$. Calcium may be of detrital, biogenic or diagenetic origin. At site MD073088 , the organic origin of $\mathrm{Br}$ is clear as testified by the overall excellent linear correlation with discrete TOC measurements $\left(r^{2}=0.87\right.$; Supplementary Fig. 3$)$ as well as with the $\delta^{13} \mathrm{C}$ and $\mathrm{C} /$ 
a



C

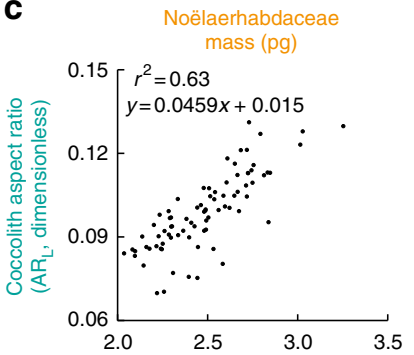

b

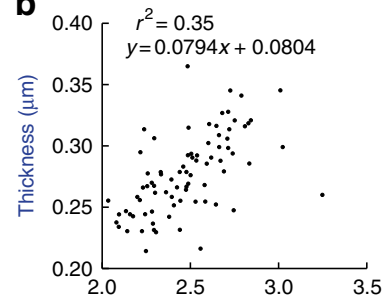

d

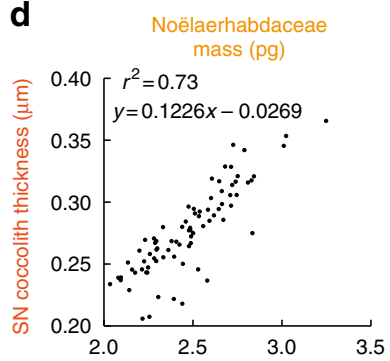



$\mathrm{N}$ values of bulk organic matter (ranging from -24.9 to $20.05 \%$ and from 7.6 to 11.5 , respectively) that cluster well within the typical ranges for well-preserved marine organic component $5^{54}$ (Supplementary Fig. 4). The sediment mostly receives carbonate-

Fig. 3 Noëlaerhabdaceae coccolith morphometrics, and their response to excepted $\left[\mathrm{CO}_{2 \mathrm{aq}}\right]$ at site MD07-3088 over the last deglaciation. a-d Relationships between coccolith mass (pg) and coccolith area (a), thickness (b), as well as coccolith aspect ratio $\left(\mathrm{AR}_{\mathrm{L}}\right)^{28}(\mathbf{c})$ and $\mathrm{SN}$ thickness ${ }^{27}$ (d) (Methods section). e-i Coccolith morphometric changes during the deglaciation: e mass $(\mathrm{pg}), \mathbf{f}$ area $\left(\mu \mathrm{m}^{2}\right)$, $\mathbf{g}$ thickness $(\mu \mathrm{m})$, h-i $\mathrm{SN}^{27}$ and $\mathrm{AR}_{\mathrm{L}}{ }^{28}$ indices (Methods section). Coccolith mass show no relationship with coccolith area, but clear positive relationships with size normalized coccolith mass indices $A R_{L}$ and $S N$ which indicates that the mass of coccoliths typically increases in proportion with their thickness. Therefore, changes in coccolith mass document changes in the degree of coccolith calcification (i.e. PIC/POC ratio). Obviously, the Noëlaerhabdaceae coccolith mass increases observed during enhanced SO upwelling associated with higher sea surface fertility conditions (yellow shading), document increased coccosphere calcite quota in response to $\mathrm{SSW}\left[\mathrm{CO}_{2 \mathrm{aq}}\right]$ rises during $\mathrm{HS} 1$ and $\mathrm{YD}$

free terrigenous material sourced from metamorphic and plutonic rocks of the Andes ${ }^{35}$ that contain negligible amounts of calciumbearing minerals (plagioclases), while $\mathrm{Ca}$ and $\mathrm{Ca} / \mathrm{Ti}$ report excellent linear correlations with $\mathrm{CaCO}_{3}\left(r^{2}=0.75\right.$ and 0.73 , respectively; Supplementary Fig. 3) thus excluding any $\mathrm{Ca}$ of terrigenous origin. As for other sites from the Chilean margin located well above the lysocline ${ }^{55}$ (Methods), it is thus reasonable to consider that $\mathrm{Ca}$ is primarily associated with biogenic carbonates, and more particularly planktonic calcifiers. Indeed, bulksediment carbonate content fluctuations mimic those observed for the $\mathrm{CaCO}_{3}$ produced by coccolithophores and planktonic foraminifera (Fig. 4, Supplementary Fig. 3; Methods). We suggest that, in our core, POC:PIC ratio changes in the sediments likely reflect changes in the $\mathrm{C}$ rain ratio (POC:PIC) (Methods). Therefore, the downcore $\mathrm{Br} / \mathrm{Ca}$ ratio is used to provide an estimate of the strength of the STP relative to the CCP, which serves as a robust tool to reconstruct decadal changes in the BCP efficiency (Fig. 4d). This record depicts highest values during the Late Glacial (19.6-17.7 ka), the Antarctic Cold Reversal (ACR; 14.1-12.0 ka) and the Mid Holocene (8.6-3.0 ka). On the other hand, significant reductions in $\mathrm{Br} / \mathrm{Ca}$ are observed at times intense SO upwelling prevailed, particularly during HS1 and the YD. These transient declines are mainly driven by changes in $\mathrm{CaCO}_{3}$ export during $\mathrm{HS} 1$ since the TOC record is characterized by increasing values during this specific time interval (Supplementary Fig. 3), while both increasing $\mathrm{CaCO}_{3}$ and relatively high yet decreasing TOC values might be associated during the YD. Furthermore, they match the pronounced peaks in surface ocean fertility (Fig. 2a-d) as well as coccolith and planktonic foraminifera abundances and masses that are well expressed by 3fold to 10-fold and up to 20-fold increases in the overall amount of burial $\mathrm{CaCO}_{3}$ produced by coccolithophores and planktonic foraminifera respectively, and coincide with prominent rises in atmospheric $\mathrm{pCO}_{2}{ }^{56}$ (Fig. 4). This increase in the CCP, associated with rising macronutrient availability and thus, enhanced fertility in the SAZ, is comparable to the 6-10 folds increase in deep-ocean PIC fluxes previously documented for naturally iron-fertilized sites from the Polar Frontal Zone compared to non-fertilized ones $^{24}$. In both cases, increased fertility is linked to a rise of about one order of magnitude of the PIC flux, thus confirming the important role of CCP in mediating the reduction of deep-ocean $\mathrm{CO}_{2}$ storage ${ }^{24}$. The impact of changing POC:PIC ratio $(1 / \rho)$ on $p \mathrm{CO}_{2}$ is shown in Fig. 5 for HS1 and the ACR, in cases for which 10 to $50 \%$ of the exported POC is preserved in the sediments (Methods). In all cases, primary production decreased sea surface $\left[\mathrm{CO}_{2 \mathrm{aq}}\right]$, as $1 / \rho$ is higher than the critical value of 0.54 for which the CCP would completely counteracts the STP. Nevertheless, 
during HS1, the efficiency of the BCP was reduced compared to the ACR owing to lower POC:PIC ratios. The SAZ thus became a net source of $\mathrm{CO}_{2}$ during $\mathrm{HS} 1$ and the $\mathrm{YD}^{15}$, due to enhanced SO upwelling of aged, $\mathrm{CO}_{2}$-enriched deep waters ${ }^{14}$ and a concomitant weakening of the BCP. Indeed, the increase in calcite production by coccolithophores and planktonic foraminifera caused a decrease in surface-ocean alkalinity (ALK) (or in other



words, an increase in $p \mathrm{CO}_{2 \mathrm{aq}}$ ), thus promoting the net outgassing of carbon from the ocean interior to the atmosphere (Fig. 5). In such a scenario, the CCP would have contributed to weaken the marine $\mathrm{BCP}$, with significant impact on atmospheric $p \mathrm{CO}_{2}$ since the very beginning of the last deglaciation. The STP was not efficient enough to offset the carbon release during the last deglaciation, in part due to the contribution of the CCP. Increased planktonic calcification in the SAZ has the potential to effectively amount to a reduction of the overall POC:PIC rain ratio in the SO (Fig. 5), with significant impacts on the net flux of $\mathrm{CO}_{2}$ from the ocean to the atmosphere ${ }^{24}$.

Our study reveals the intrinsic link between BCP strength and changes in Southern Ocean circulation in coordinating the

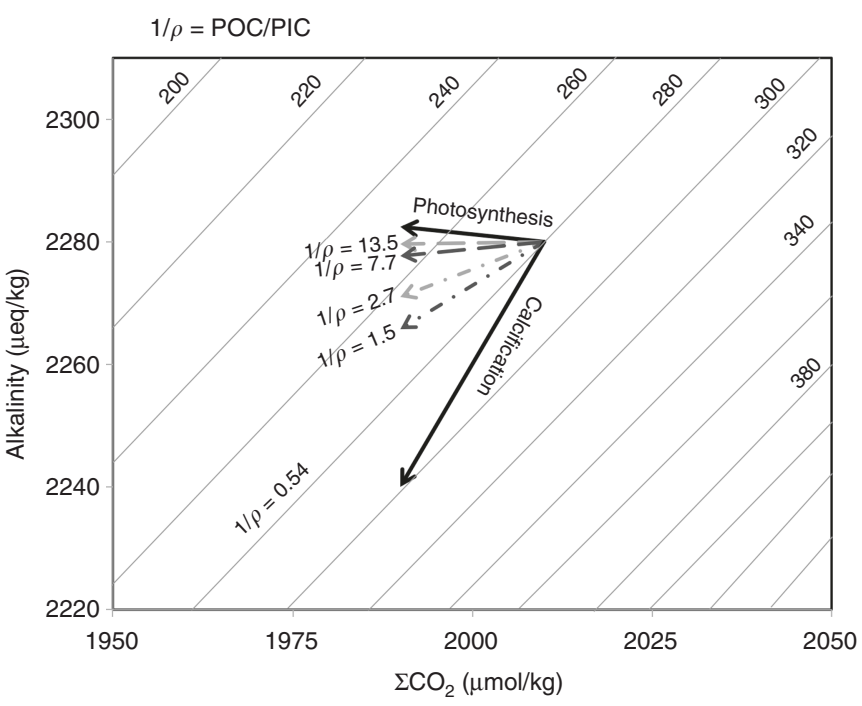

Fig. 5 Influence of soft tissue and carbonate counter pumps on the $\mathrm{CO}_{2}$ partial pressure of surface waters, as a function of the $\mathrm{POC} / \mathrm{PIC}$ rain ratio $(1 / \rho)$. Solid black line isocontours represent $\mathrm{pCO}_{2}$ ( $\mu$ atm) for constant salinity $(34 \% \circ)$, temperature $\left(14^{\circ} \mathrm{C}\right)$, and depleted phosphate $(0.5 \mu \mathrm{mol} /$ $\mathrm{kg})$ and silicate $(3 \mu \mathrm{mol} / \mathrm{kg})$ contents. The solid black arrows represent the effect of biogenic export production in the case of photosynthesis and calcification only. The dashed (or dot-dashed) black and grey arrows illustrate the influence of the biological pump (and particularly the CCP) during the HS1 relative to the ACR, i.e., when $1 / \rho$ decreases by a factor of 1.8 , assuming that 10 (or $50 \%$ ) of the exported POC has been preserved within the sediment, i.e., under two probable export production conditions at site MD07-3088

Fig. 4 Subantarctic carbonate counter pump strength and biological pump efficiency coupled with circulation pattern and atmospheric $p \mathrm{CO}_{2}$ during the last deglaciation. a-c Noëlaerhabdacea, coccolith and planktonic foraminifera calcite masses ( $\mathrm{mg} / \mathrm{g}$ of sediment) at site MD07-3088, with errors bars of $\pm 3 \%$ and $\pm 20 \%$, respectively. $\mathbf{d ~ B r} / \mathrm{Ca}$ ratio as an indicator of $\mathrm{POC} / \mathrm{PIC}$ rain ratio and thus biological carbon pump efficiency (see Supplementary Fig. 3). e $\Delta \delta^{13} C=\delta^{13} C_{G \text {. bulloides }}-\delta^{13} C_{C \text {. wuellerstorfi }}{ }^{14}$. f Atmospheric $\mathrm{pCO}_{2}$ from WDC ${ }^{56}$. Smoothed curves (thick lines of a-c, e and $\mathbf{d}$ ) use three and eleven-point moving averages respectively. LG and LGIT are for Late Glacial and Last Glacial-Interglacial Transition, respectively. Yellow shading marks periods of reinvigorated SO upwelling (associated with enhanced sea surface fertility conditions and higher $\left.\left[\mathrm{CO}_{2 \mathrm{aq}}\right]\right)$ during the last deglaciation, in conjunction to higher CCP strength and subdued biological pump efficiency, at times of increased atmospheric $p \mathrm{CO}_{2}$ 
partitioning of carbon between the ocean interior and the atmosphere during the last glacial termination. As such, much more attention should be brought to the response of calcifying plankton at other sites within the Southern Ocean but also in low latitudes, to better quantify their relative contribution in the past global $p \mathrm{CO}_{2}$ budget.

\section{Methods}

Material and site description. The CALYPSO core MD07-3088 was retrieved during the IMAGES PACHIDERME (MD 159) expedition by the French R/V Marion Dufresne off Southern Chile $\left(46^{\circ} 04\right.$ S; $\left.075^{\circ} 41 \mathrm{~W}\right)$, at a water depth of 1536 $\mathrm{m}$, i.e., well above the modern lysocline (around $3700 \mathrm{~m})^{55}$ (Fig. 1). The site is bathed by the upper layer of southward flowing Pacific Deep Water (PDW), at the boundary with northward flowing AAIW ${ }^{2}$. The surface waters above the site are on the direct northward path of the SSW that is fed by the DIC- and nutrient-rich surface waters of the Antarctic Zone. These Antarctic and Subantarctic surface waters represent the source for AAIW/SAMW (i.e., intermediate depth waters), and have been hypothesized to be a major conduit through which high-latitude ocean changes are transmitted to the lower latitudes ${ }^{2}$. Core MD07-3088 has the advantage of being located within the Subantarctic Zone, well to the south and well to the north of the Tropical and Polar Frontal Zones, respectively, and has probably not been affected by potential shift of the Subtropical Front (STF) or the Subantarctic Front (SAF) in the past. The southern tip of Chile is the only continental mass intercepting the westerly winds within this latitude range, generating a zone of high precipitations that result in high fluvial sediment supplies to the South Pacific Ocean. Since any significant sediment reworking is precluded at site MD07$3088^{14}$, the extremely high sedimentation rates recorded at site MD07-3088 ( 300 $\mathrm{cm} / \mathrm{kyr}$ during the Last Glacial and $\sim 60 \mathrm{~cm} / \mathrm{kyr}$ during the deglaciation and the Holocene ${ }^{14}$ ) provide a rare opportunity to study productivity patterns of the Subantarctic Zone with decennial to centennial resolution during the last glacial termination.

Age models of core MD07-3088 and ODP cores 1238 and 1233. The MD073088 age model has been determined using $\mathrm{SH}_{1}{ }^{14}$ as the ${ }^{14} \mathrm{C}$ Southern Hemisphere calibration curve $\mathrm{e}^{57}$. In order to compare our micropaleontological and geochemical records with ODP sites 1233 and 1238 located in the SouthEastern Pacific (SEP, $41.0^{\circ} \mathrm{S}, 74.4^{\circ} \mathrm{W}$ ) and the Eastern Equatorial Pacific (EEP, $1.5^{\circ}$ $\mathrm{S}, 82.5^{\circ} \mathrm{W}$ ) respectively, we established a common age model for these cores to test temporal phasing since the late glacial period. For ODP site 1233, we use the recently updated age model of ref. ${ }^{58}$ and based on the reservoir ${ }^{14} \mathrm{C}$ age estimates by ref. ${ }^{14}$. The age model of ODP site 1238 is based on $10 \mathrm{AMS}{ }^{14} \mathrm{C}$ dates obtained on planktonic foraminifera Neogloboquadrina dutertrei using a constant local seasurface reservoir ${ }^{14} \mathrm{C}$ age $\left(R_{\mathrm{S}}\right)$ correction $(\Delta R=72 \pm 35 \mathrm{yr})$ based on previous regional estimates ${ }^{15}$. However, this approach did not consider the possible advection of old subsurface waters in particular during the deglaciation as suggested by previous studies at local and regional scales ${ }^{59,60}$. Since no independent $R_{\mathrm{S}}$ estimates are available in literature for the EEP, other methods must be considered in order to obtain a robust common stratigraphic framework. Hence, we first compared the planktonic foraminifera $\delta^{13} \mathrm{C}$ records of the two cores versus conventional ${ }^{14} \mathrm{C}$ age $e^{14,15}$, the $\delta^{13} \mathrm{C}$ record for ODP 1238 representing sub-surface record as it is measured on $N$. dutertrei (Supplementary Fig. 1). In general, the first order (and most of the second order) changes in planktonic $\delta^{13} \mathrm{C}$ are recorded in both cores. These results also match co-existing benthic-planktonic foraminifera (B-P) ${ }^{14} \mathrm{C}$ and $\delta^{13} \mathrm{C}$ differences in core MD07-3088, indicating variations in oceanic ventilation (see ref. ${ }^{14}$ for extensive discussion) versus conventional ${ }^{14} \mathrm{C}$ age. Similarly, the ventilation changes expressed in term of upwelling increases observed in core MD07-3088 were coeval with changes in surface ocean carbon content in the EEP ${ }^{15}$ (Supplementary Fig. 1). Through these comparisons, it is clear that enhanced mixing (between $\sim 15$ and $\sim 13.1{ }^{14} \mathrm{C}$ ka, and between $\sim 12$ and $\sim 10.5$ ${ }^{14} \mathrm{C} \mathrm{ka}$ ) was characterized by a lower difference between planktonic and benthic carbon isotope signatures, and are globally synchronous with oceanic $p \mathrm{CO}_{2}$ changes. This finding supports the hypothesis that the planktonic foraminiferal records correspond to the water masses with the same history (SAW and SAMW) presenting similar radiocarbon contents. This allows us to deduce that EEP and SEP were characterized by similar reservoir ${ }^{14} \mathrm{C}$ age changes at least since the last deglaciation.

Coccolith slides and morphometric measurements (SYRACO). Slides of 80 samples were prepared at GEOPS laboratory. Briefly, $\sim 0.03 \mathrm{~g}$ of sediment was diluted in $28 \mathrm{~mL}$ Luchon water $(\mathrm{pH}=8$, bicarbonate $=78.1 \mathrm{mg}$ per liter, total dissolved solid $=83 \mathrm{~g}$ per liter) within a flat beaker, and settled on a $12 \times 12 \mathrm{~mm}$ coverslip for $4 \mathrm{~h} 30 \mathrm{~min}$. The coverslip was then oven-dried at $70{ }^{\circ} \mathrm{C}$, and mounted on slides with NOA74. This technique ensures a homogenous distribution of coccoliths and allows quantifying the amount of material per gram of sediment ${ }^{61}$ as follow:

$$
A=(\mathrm{Nc} \times \mathrm{Sf}) /(\mathrm{No} \times \mathrm{So} \times \mathrm{Ws})
$$

where $A$ is the number of coccoliths per gram of sediment; $\mathrm{Nc}$ is the number of counted coccoliths (between 505 and 3900); Sf is the surface of the flat beaker $\left(3117 \mathrm{~mm}^{2}\right)$ in which suspended sediments (and coccoliths) settle; No is the number of view fields (165); So is the surface of a view fields $\left(0.01 \mathrm{~mm}^{2}\right)$ and Ws is the weight of sediment that settled in the flat beaker (between 0.018 and $0.043 \mathrm{mg}$ ).

For each sample, abundance and morphometric analyses (length, width, area, mass) of individual coccoliths were automatically obtained with an average of 1591 coccoliths per sample, by the SYRACO software using automated microscope (Leica DM6000B). SYRACO performs pattern recognition under cross-polarized light using artificial neural networks ${ }^{61}$. It detects and classifies most of the coccoliths present in the samples throughout the time series (mainly represented by Emiliania huxleyi, Gephyrocapsa muellerae, Gephyrocapsa oceanica, Calcidiscus leptoporus, and Helicosphaera carteri). Coccolith mass were directly deduced based on a quasi-linear relationship that exists between their brightness (birefringence in grey scale colors) and their thickness under cross-polarized light. Because this method applies on coccoliths thinner than $1.55 \mu \mathrm{m}$ that exhibit grey scale colors ${ }^{61}$, we interpret only thickness and mass measurements for Noëlaerhabdaceae coccoliths. Indeed, their abundance and morphometric parameters show standard error of $\pm 1 \%$ and $\pm 3 \%$ in each sample respectively. Morphometric analyses for $C$. leptoporus and H. carteri that display third-order interference colors (and thus increasing standard errors), are only presented within the Supplementary Information (Supplementary Fig. 2).

Since coccolith mass are not independent of coccolith size, we calculated sizenormalized thickness indices for all the Noëlaerhabdaceae coccoliths within each sample to verify that changes in coccolith mass represent changes in calcification, according to the two equations that exist so far ${ }^{27,28,44}$ (Fig. 3). We obtained the Size Normalized Thickness index $\mathrm{SN}^{27,44}$ that considers coccolith thickness related to cell surface area as follow:

$$
\mathrm{SN}_{\text {thickness }}(\mu \mathrm{m})=[(\mathrm{ML}-\mathrm{CL}) \times S]+\mathrm{CT}
$$

Where ML is the mean coccolith length over the whole time serie, $C L$ is the length of coccolith X in Sample A, $S$ is the slope of the linear regression between coccolith length and coccolith thickness for all coccolith in Sample A, and CT is the original thickness of coccolith $\mathrm{X}$ in Sample A (i.e., coccolith mass/coccolith area ratio).

We calculated the lateral cross-sectional aspect ratio $\mathrm{AR}_{\mathrm{L}}{ }^{28}$ that considers coccolith thickness related to cell volume as follow:

$$
\mathrm{AR}_{\mathrm{L}}(\text { dimensionless })=T_{\mathrm{L}} / \sqrt{ } A_{\mathrm{L}}
$$

where $T_{\mathrm{L}}$ and $A_{\mathrm{L}}$ are the thickness and the area of coccolith X in Sample A respectively. $T_{\mathrm{L}}=M_{\mathrm{L}} / A_{\mathrm{L}}$, i.e. coccolith mass $\left(M_{\mathrm{L}}\right) /$ coccolith area $\left(A_{\mathrm{L}}\right)$.

Coccolith area and mass values as well as $\mathrm{SN}_{\text {thickness }}$ and $\mathrm{AR}_{\mathrm{L}}$ values obtained herein are in the same order of magnitude than published data using similar birefringence-based methods $\mathrm{s}^{27,28,39}$.

Coccolith taxonomy and preservation. More than $96 \%$ of the assemblages were composed of five species: Emiliania huxleyi, Gephyrocapsa muellerae, Gephyrocapsa oceanica, Calcidiscus leptoporus, and Helicosphaera carteri. As for modern settings, Emiliania and Gephyrocapsa, that constitute the Noëlaerhabdaceae family, represent the most prominent genera (from 81 to $97 \%$ of the assemblages) and reflect the main patterns of the total coccoliths. For that reason, but also because smallest Emiliania and Gephyrocapsa from the SE Pacific present a wide range of morphotypes $^{62}$ that are not easily classified under light microscope, we mainly considered the Noëlaerhabdaceae family instead of Emiliania and Gephyrocapsa species. Besides, species assignations within the Noëlaerhabdaceae family are primarily based on size ${ }^{43}$, and all narrowly restricted size classes of Noëlaerhabdaceae present the same main patterns (Supplementary Fig. 2). Indeed, generally, $<3 \mu \mathrm{m}$ Noëlaerhabdaceae represent $E$. huxleyi type C and small Gephyrocapsa; 3-4 $\mu \mathrm{m}$ Noëlaerhabdaceae are associated to E. hyxleyi type B/C and G. muellerae; and $>4$ $\mu \mathrm{m}$ Noëlaerhabdaceae document E. huxleyi type A and B and G. oceanica patterns ${ }^{43,62}$

This study gathers specific morphological parameters of exactly 152,809 coccoliths that appear to reflect primary biomineralization features. The core MD07-3088 has been retrieved well above the lysocline. It is mainly made of homogenous fine-grained material that, together with high sedimentation rates ( $\sim 300 \mathrm{~cm} / \mathrm{kyr}$ during the Last Glacial and $\sim 60 \mathrm{~cm} / \mathrm{kyr}$ during the deglaciation and the Holocene ${ }^{14}$ ), prevent post-depositional fluid circulations. Besides, dissolution processes trigger a strong differential preservation of coccoliths keeping resistant specimens and losing delicate ones. The most delicate morphotypes belong to the Noëlaerhabdaceae family that represent the main coccolith of the assemblage. The smallest Noëlaerhabdaceae $(<3 \mu \mathrm{m}$, i.e., mainly $E$. huxleyi type $\mathrm{C}$ and small Gephyrocapsa) depict the same exact pattern as the larger ones, with higher masses when the oceanic carbon reservoir is reconnected to the surface waters and bring $\mathrm{CO}_{2}$-rich waters into the photic zone (Supplementary Fig. 2), while such conditions could have favored the dissolution of coccoliths in the water column. At last, the three main increases observed during the deglaciation in the mean Noëlaerhabdaceae coccolith mass, would not be biased by diagenetic overgrowth that would also affect C. leptoporus and to a lesser degree H. carteri, that generally depict however, reducing coccolith masses during these time intervals (Supplementary Fig. 2). Indeed, diagenetic processes (dissolution or overgrowth) 
would simultaneously impact all coccolith morphotypes, without any discrimination between morphotypes.

Foraminifera abundance and mass data. Planktonic foraminifera assemblages were determined at the LSCE (Laboratoire des Sciences du Climat et de l'Environnement) counting at least 300 specimens per sample. From three different depths $(570,950$, and $990 \mathrm{~cm})$, we weighted 30 individuals from the most abundant species (Neogloboquadrina pachyderma (sinistral and dextral coilings), Globigerina bulloides, Globorotalia inflata, Turborotalita quinqueloba and Globigerinita glutinata) for different sizes ( $>450 \mu \mathrm{m}, 315-450 \mu \mathrm{m}, 250-315 \mu \mathrm{m}, 150-250 \mu \mathrm{m})$ to determine their mean weight. For this core, we obtained mean weights of: $7 \pm 2 \mu \mathrm{g}$ for N. pachyderma, T. quinqueloba, and G. glutinata, $18 \pm 3 \mu \mathrm{g}$ for G. bulloides, and $19 \pm 5 \mu \mathrm{g}$ for G. inflata. For Globigerinella calida, Globigerina falconensis, G. ruber, Globigerina hexagonus (representing $<2 \%$ in all samples), Neogloboquadrina dutertrei and Hastigerina digitata (representing $<0.5 \%$ in all samples), we assumed a mean weight similar to G. bulloides. At last, for Globorotalia truncatulinoides, Globorotalia crassaformis, and Globorotalia hirsuta, we assumed a mean weight similar to $G$. inflata. From the assemblage and the mean weight of the different species, we estimated the planktonic foraminifera calcite mass for each sample, $\mathrm{CaCO}_{3 \text { pl.foram.mass }}$ in $\mathrm{mg} / \mathrm{g}$ as follow:

$$
\mathrm{CaCO}_{3 \text { pl.foram.mass }}=\frac{N \times 2^{\text {split }}}{M} \times \sum_{i}\left(m_{i} \times X_{i}\right)
$$

where $N$ is the total amount of determined foraminifera $(\geq 300)$, split is the number of split done before establishing a planktonic assemblage, $M$ is the total dry mass of the sample $(\mathrm{g}), m_{i}$ the mean weight of the species $i(\mathrm{mg})$, and $X_{i}$ the percentage of the species in the sample.

This approach is a first order estimate of the foraminifera mass percentage as it does not fully take into account smaller species often $<150 \mu \mathrm{m}$ (such as G. uvula and partly T. quinqueloba) and juveniles. Besides, for 16 depths (covering LGM, HS1, ACR, YD and the Holocene), we weighted 6 to 60 specimens of G. bulloides (the most abundant foraminifera) from different size ranges (150-200, 200-250, $250-315,315-355,355-400$, and $400-450 \mu \mathrm{m}$ ) in order to statistically characterize potential weight changes within a narrow size range. Mean weights for the different size classes decrease of about 20\% from LGM to Holocene, and of about 7 and $18 \%$ during HS1 and YD respectively. If similar weight decreases are observed within the other planktonic species, the magnitude of the changes in the overall weight ( $\sim 20 \%)$ would be not sufficient enough to significantly change the estimated planktonic foraminifera mass flux. Indeed, because of the drastic increases within the planktonic foraminifera abundance during these time intervals (more than one order of magnitude), fluctuations in the planktonic foraminifera weights would imply changes in the flux of planktonic foraminifera calcite mass that remain within the error bars.

Total $\mathrm{CaCO}_{3}$ and organic carbon analyses. Total $\mathrm{CaCO}_{3}$ was determined at GEOPS laboratory using the vacuum-gasometric technique with a precision better than $\pm 2 \%$. $100 \mathrm{mg}( \pm 5)$ of crushed-dried sediments react with a few milliliters of $\mathrm{HCl} 6 \mathrm{~N}$ in a hermetic reaction chamber $\left(22.4 \mathrm{~cm}^{3}\right)$ that is connected to a manometer MANO MEX2-420 that measures the amount of outgassed $\mathrm{CO}_{2}$. The system is calibrated so that $100 \mathrm{mg}$ of $\mathrm{CaCO}_{3}(100 \%)$ trigger a pressure rise to 1 bar.

Total organic carbon and nitrogen contents together with organic matter $\delta^{13} \mathrm{C}$ analyses were obtained at the LSCE, using an Elementary Analyzer (Flash EA 1112) and the online continuous EA coupled with an Isotopic Ratio Mass Spectrometer $\left(\right.$ Finigan Delta $+\mathrm{XP}$ ). The results are expressed in $\% \mathrm{C}, \% \mathrm{~N}$, and in $\delta^{13} \mathrm{C}$ per $\mathrm{mL}$ (\%) against the international standard V-PDB (Vienna Pee Dee Belemnite). Error margin is defined according to the source linearity checked for each run based on internal home-standard $\left(\Delta \mathrm{C}<0.03 \%\right.$ and $\Delta \delta^{13} \mathrm{C}<0.2 \%$ ). A aliquot of $<250 \mu \mathrm{m}$ of dry sediment is softly leached with ultra-pure $\mathrm{HCl} 6 \mathrm{~N}$ to remove carbonate and dry at $50^{\circ} \mathrm{C}$. The samples were then crushed in a pre-combusted glass mortar for homogenization prior to carbon, nitrogen content and $\delta^{13} \mathrm{C}$ analyses.

XRF scanner measurements. The high-resolution elemental analysis of $\mathrm{Br}$ and $\mathrm{Ca}$ was performed using an Avaatech profiling X-ray fluorescence (XRF) core scanner at Royal Netherland Institute for Sea Research (NIOZ) at a $1 \mathrm{~cm}$ downcore resolution. The external reproducibility of this core-scanner for $\mathrm{Br}$ and $\mathrm{Ca}$ in the range of the measurements is below $2 \%(1 \sigma)$.

\section{Sedimentary POC: PIC ratio vs POC: PIC rain ratio $(\mathbf{1} / \rho)$. It remains difficult to} evaluate the influence of changes in the TOC relative to the $\mathrm{CaCO}_{3}(\mathrm{POC} / \mathrm{PIC}$ ratio, $1 / \rho)$ water column export and sedimentary burial on past $p \mathrm{CO}_{2}$ variability. Indeed, the amount of particulate organic and inorganic carbon in the sediments is not necessarily directly related to the fraction exported from the surface waters. While it is probably reasonable to assume that the $\mathrm{CaCO}_{3}$ accumulated in the sediment is representative of the PIC exported from the mixed layer to deep waters as core MD07-3088 was retrieved well above the lysocline (located around $3700 \mathrm{~m}$ depth nowadays ${ }^{55}$ ), it is probably not the case for TOC that might be more easily mineralized within the water column and upper sediments. However, at site MD07-3088, the combination of high sedimentary TOC contents (up to $1.9 \%$ ), high sedimentation rates, and homogeneous fine-grained lithology, lead us to assume that post-depositional remineralization processes associated to $\left(\mathrm{O}_{2}\right.$-rich $)$ fluid circulations within the sediments must be of secondary importance. Moreover, it has been shown that it is in fact the oxygen exposure time that determines organic carbon degradation (i.e., ref. ${ }^{63}$ ), and based on the considerations above, we infer that labile organic compounds must have been buried rapidly, minimizing the potential for selective alteration. There is no doubt that remineralization processes that occurred within the water column (and particularly the twilight zone), altered the downward flux of POC, and thus the efficiency of carbon sequestration. However, the latitudinal distribution pattern of POC in surface sediments along the Chilean margin ${ }^{55}$ reflects satellite-derived surface-ocean chlorophyll concentrations ${ }^{64}$, which indicates that sedimentary TOC concentrations primarily reflect OC export rather than selective degradation processes within the water column. Besides, the high-latitude, iron-fertilized, near-shore ecosystem that characterize site MD07-3088, seems to be the perfect candidate to promote the sinking of organic matter to the deep seafloor ${ }^{65-67}$. Therefore, in order to consider a wide range of POC transfer efficiencies ${ }^{65-67}$, we have tested the impact of BCP for HS1 and ACR, in cases where 10 to $50 \%$ of the exported POC is preserved within the sediments. Figure 5 indicates the influence of $1 / \rho$ on seawater carbonate chemistry for cases ranging from photosynthetic processes to calcification processes only (solid black arrows) and for $10 \%$ to $50 \%$ of the TOC exported flux preserved in core MD07-3088 sediments for the HS1 and ACR periods.

Data availability. The data that support the findings of this study are available from the corresponding author (S.D.-A.) upon reasonable request.

Received: 26 July 2017 Accepted: 8 May 2018

Published online: 19 June 2018

\section{References}

1. Marshall, J. \& Speer, K. Closure of the meridional overturning circulation through Southern Ocean upwelling. Nat. Geosci. 5, 171-180 (2012).

2. Strub, P. T., Mesias, J. M., Montecino, V., Ruttlant, J., Salinas, S. Coastal ocean circulation off Western South America in The Global Coastal Ocean, Regional Studies and Syntheses, 273-315 (Wiley, Hoboken, NJ, 1998).

3. Martin, J. H., Gordon, R. M. \& Fitzwater, S. E. Iron in Antarctic waters. Nature 345, 156-158 (1990).

4. Pollard, R. T. et al. Southern Ocean dee-water carbon export enhanced by natural iron fertilization. Nature 457, 577-580 (2009).

5. Morrison, A., Frölicher, T., Sarmiento, J., Upwelling in the Southern Ocean. Physics Today 68, 27-32 (2015).

6. Ferrari, R., et al. Antartic sea ice control on ocean circulation in present and glacial climates. Proc. Natl Acad. Sci. USA 111, 8753-8758 (2014).

7. Adkins, J. F., McIntyre, K. \& Schrag, D. P. The salinity, temperature, and $\delta^{18} \mathrm{O}$ of the glacial deep ocean. Science 298, 1769-1773 (2002).

8. Watson, A. J., Vallis, G. K., Nikurashin, M. Southern Ocean buoyancy forcing of ventilation and glacial atmospheric $\mathrm{CO}_{2}$. Nat. Geosci. 8, 861-864 (2015).

9. Kumar, N. et al. Increased biological productivity and export production in the glacial Southern Ocean. Nature 378, 675-680 (1995).

10. Martinez-Garcia, A. et al. Iron fertilization of the subantarctic ocean during the last Ice Age. Science 343, 1347-1350 (2014).

11. Sigman, D. M., Hain, M. P. \& Haug, G. H. The polar ocean and glacial cycles in atmospheric $\mathrm{CO}_{2}$ concentration. Nature 466, 47-55 (2010).

12. Jaccard, S. L., Galbraith, E. D., Martinez-Garcia, A. \& Anderson, R. F. Covariation of deep Southern Ocean oxygenation and atmospheric $\mathrm{CO}_{2}$ through the last ice age. Nature 530, 207-210 (2016).

13. Skinner, L. C., Fallon, S., Waelbroeck, C., Michel, E. \& Barker, S. Ventilation of the deep Southern Ocean and deglacial $\mathrm{CO}_{2}$ rise. Science 328, 1147-1151 (2010).

14. Siani, G. et al. Carbon isotope records reveal precise timing of enhanced Southern Ocean upwelling during the last deglaciation. Nat. Commun. 4, 2758 (2013).

15. Martinez -Boti, M. A. et al. Boron isotope evidence for oceanic carbon dioxide leakage during the last deglaciation. Nature 518, 219-222 (2015).

16. Galbraith, E. D. \& Jaccard, S. L. Deglacial weakening of the oceanic soft tissue pump: global constraints from sedimentary nitrogen isotopes and oxygenation proxies. Quat. Sci. Rev. 109, 38-48 (2015).

17. Kohfeld, K. E., Le Quéré, C., Harrison, S. P. \& Anderson, R. F. Role of marine biology in Glacial-Interglacial $\mathrm{CO}_{2}$ cycles. Science 308, 74-78 (2005).

18. Martinez-Garcia, A. et al. Links between iron supply, marine productivity, sea surface temperature, and $\mathrm{CO}_{2}$ over the last 1.1. Ma. Paleoceanography $\mathbf{2 4}$ PA1207 (2009).

19. Muratli, J. M., Chase, Z., Mix, A. C. \& McManus, J. Increased glacial-age ventilation of the Chilean margin by Antarctic Intermediate Water. Nat. Geosci. 3, 23-26 (2010). 
20. Lamy, F. et al. Increased dust deposition in the Pacific Southern Ocean during glacial periods. Science 343, 403-407 (2014).

21. Gottschalk, J., et al. Biological and physical controls in the Southern Ocean on past millennial-scale atmospheric $\mathrm{CO}_{2}$ changes. Nat. Commun. 7, 11539 (2016).

22. Mahowald, N. M., et al. Change in atmospheric mineral aerosols in response to climate: last glacial period, pereindustrial, modern, and doubled carbon dioxide climates. J. Geophys. Res. 11, D10202 (2006).

23. Tagliabue, A., Aumont, O., Bopp, L. The impact of different external sources of iron on the global carbon cycle. Geophys. Res. Lett. 41, 920-926 (2014).

24. Salter, I., et al. Carbonate counter pump stimulated by natural iron fertilization in the Polar frontal zone. Nat. Geosci. 7, 885-889 (2014).

25. Winter, A., Siesser, W. G. (eds) Coccolithophores. 242p (Cambridge University Press, Cambridge, 1994).

26. Archer, D., Maier-Reimer, E. Effect of deep-sea sedimentary calcite preservation on atmospheric $\mathrm{CO}_{2}$ concentration. Nature 367, 260-263 (1994).

27. Bolton, C. T. et al. Decrease in coccolithophore calcification and $\mathrm{CO}_{2}$ since the middle Miocene. Nat. Commun. 7, 10284 (2016)

28. McClelland, H. L. O. et al. Calcification response of a key phytoplankton family to millennial- scale environmental change. Sci. Rep. 6, 34263 (2016)

29. Saavedra-Pellitero, M., Flores, J. A., Lamy, F., Sierro, F. J. \& Cortina, A. Coccolithophore estimates of paleotemperature and paleoproductivity changes in the southeast Pacific over the past 27 kyr. Paleoceanography 26, PA1201 (2011).

30. Anderson, R. et al. Wind-driven upwelling in the Southern Ocean and the deglacial rise in atmospheric $\mathrm{CO}_{2}$. Science 323, 1443-1448 (2009).

31. Haddam, N. A., et al. Improving past sea surface temperature reconstructions from the Southern Hemisphere oceans using planktonic foraminiferal census data. Paleoceanography 31, 822-837 (2016).

32. DiFiore, P. J. et al. Nitrogen isotope constraints on subantarctic biogeochemistry. J. Geophys. Res. 11, C08016 (2006).

33. Flores, J. A., Filippelli, G. M., Sierro, F. J., Latimer, J. The "White Ocean" hypothesis: a late Pleistocene Southern Ocean governed by coccolithophores and driven by phosphorus. Front. Microbiol. 3, 233 (2012).

34. Chase, Z., McManus, J., Mix, A. C. \& Muratli, J. Southern Ocean and glaciogenic nutrients control diatom export production on the Chile margin. Quat. Sci. Rev. 99, 135-145 (2014).

35. Siani, G. et al. Late Glacial to Holocene terrigenous sediment record in the Northern Patagonian margin: paleoclimate implications. Paleogeogr. Paleoclimatol. Paleoecol. 297, 26-36 (2010).

36. Raiswell, R. et al. Contributions from glacially derived sediment to global iron (oxy-hydr)oxide cycle: implications for iron delivery to the oceans. Geochim. Et. Cosmochim. Acta 70, 2765-2780 (2006)

37. Wang, X. T. et al. Deep-sea coral evidence for lower Southern Ocean surface nitrate concentrations during the last ice age. PNAS 114, 3352-3357 (2017).

38. Saavedra-Pellitero, M., Flores, J. A., Baumann, K. H. \& Sierro, F. J. Coccolith distribution patterns in surface sediments of Equatorial and Southeastern Pacific Ocean. Geobios 43, 131-149 (2010).

39. Beaufort, L. et al. Sensitivity of coccolithophores to carbonate chemistry and ocean acidification. Nature 476, 80-83 (2011).

40. Meier, K., Berger, C. \& Kinkel, H. Increasing coccolith calcification during $\mathrm{CO}_{2}$ rise of the penultimate deglaciation (Terminaison II). Mar. Micropaleontol. 112, 1-12 (2014).

41. Horigome, M. T. et al. Environmental controls on the Emiliania huxleyi calcite mass. Biogeosciences 11, 2295-2308 (2014).

42. Henderiks, J. Coccolithophore size rules - reconstructing ancient cell geometry and cellular calcite quota from fossil coccoliths. Mar. Micropaleontol. 67, 143-154 (2008).

43. Young, J. R. et al. A guide to extant coccolithophore taxonomy. J. Nannoplankton Res. Spec. Issue 1, 1-125 (2003).

44. O'Dea, S. A., et al. Coccolithophore calcification response to past ocean acidification and climate change. Nat. Commun. 5, 5363 (2014).

45. Riebesell, U. et al. Reduced calcification of marine plankton in response to increased atmospheric $\mathrm{CO}_{2}$. Nature 407, 364-367 (2000).

46. Hoppe, C. J. M., Langer, G. \& Rost, B. Emiliania huxleyi shows identical responses to elevated $\mathrm{pCO}_{2}$ in TA and DIC manipulations. J. Exp. Mar. Biol. Ecol. 406, 54-62 (2011).

47. Iglesias-Rodriguez, M. D. et al. Phytoplankton calcification in a high- $\mathrm{CO}_{2}$ world. Science 320, 336-340 (2008).

48. Bolton, C. T. \& Stoll, H. M. Late Miocene threshold response of marine algae to carbon dioxide limitation. Nature 500, 558-562 (2013).

49. Henderiks, J. \& Pagani, M. Refining ancient carbon dioxide estimates: significance of coccolithophore cell size for alkenone-based $\mathrm{pCO}_{2}$ records. Paleoceanography 22, PA3202 (2007).

50. Hannisdal, B., Henderiks, J. \& Liow, L. H. Long-term evolutionary and ecological responses of calcifying phytoplankton to changes in atmospheric $\mathrm{CO}_{2}$. Glob. Change Biol. 18, 3504-3516 (2012).
51. Saavedra-Pellitero, M., Baumann, K. H. \& Ullermann, J. Marine isotope stage 11 in the Pacific sector of the Southern Ocean, a coccolithophore perspective. Quat. Sci. Rev. 158, 1-14 (2017).

52. Mayer, L. M., Schick, L. L., Allison, M. A., Ruttenberg, K. C. \& Bentley, S. J. Marine vs. terrigenous organic matter in Louisiana coastal sediments: The uses of bromine:organic carbon ratios. Mar. Chem. 107, 244-254 (2007).

53. Ziegler, M., Jilbert, T., de Lange, G. J., Lourens, L. J., Reichart, G. J. Bromine counts from XRF scanning as an estimate of the marine organic carbon content of sediment cores. Geochem. Geophys. Geosyst. 9, Q05009 (2008).

54. Meyers, P. A. Preservation of elemental and isotopic source identification of sedimentary organic matter. Chem. Geol. 114, 289-302 (1994).

55. Hebbeln, D., Marchant, M., Freudenthal, T. \& Wefer, G. Surface sediment distribution along the Chilean continental slope related to upwelling and productivity. Mar. Geol. 164, 119-137 (2000).

56. Marcott, S. A. et al. Centennial-scale changes in the global carbon cycle during the last deglaciation. Nature 514, 616-619 (2014).

57. Hogg, A. G. et al. SHCal13 Southern hemisphere calibration, 0-50,000 years cal BP. Radiocarbon 55, 1889-1903 (2013).

58. Lamy, F. et al. Glacial reduction and millennial-scale variations in Drake Passage throughflow. Proc. Natl Acad. Sci. USA 112, 13496-13501 (2015).

59. Marchitto, T. M., Lehman, S. J., Ortiz, J. D., Fluckiger, J. \& van Geen, A. Marine radiocarbon evidence for the mechanism of deglacial atmospheric $\mathrm{CO}_{2}$ rise. Science 316, 1456-1459 (2007).

60. Umling, N. E., \& Thunnel, R. C. Synchronous deglacial thermocline and deepwater ventilation in the eastern equatorial Pacific. Nat. Commun. 8, 14203 (2017).

61. Beaufort, L., Barbarin, N. \& Gally, Y. Optical measurements to determine the thickness of calcite crystals and the mass of thin carbonate particles such as coccoliths. Nat. Protoc. 9, 633-642 (2014).

62. Saavedra-Pellitero, M., Baumann, K. H., Flores, J. A. \& Gersonde, R. Biogeographic distribution of living coccolithophores in the Pacific sector of the Southern Ocean. Mar. Micropaleontol. 109, 1-20 (2014).

63. Hartnett, H. E., Keil, R. G., Hedges, J. I., and Devol, A. H. Influence of oxygen exposure time on organic carbon preservation in continental margin sediments. Nature 391, 572-574 (1998).

64. Thomas, A. C., Huang, F., Strub, P. T. \& James, C. Comparison of the seasonal and interannual variability of phytoplankton pigment concentrations in the Peru and California current systems. J. Geophys. Res. 99(C4), 7355-7370 (1994).

65. Buesseler, K. O. The decoupling of production and particulate export in the surface. Glob. Biogeochem. Cycles 12, 297-310 (1998).

66. Dunne, J. P., Sarmiento, J. L. \& Gnanadesikan, A. A synthesis of global particle export from the surface ocean and cycling through the ocean interior and on the seafloor. Glob. Biogeochem. Cycles 21, GB4006 (2007).

67. Smetacek, V. et al. Deep carbon export from a Southern iron-fertilized diatom bloom. Nature 487, 313-319 (2012).

68. Schlitzer, R. Ocean Data View http://odv.awi.de (2012).

69. Garcia, H. E., et al. in NOAA Atlas NESDIS 66 (ed. Levitus, S.) 216 pp (U.S. Government Printing Office, Washington D.C., 2009).

70. Orsi, A. H., Whitworth, T. III \& Nowlin, W. D. Jr. On the meridional extent and fronts of the Antarctic Circumpolar Current. Deep Sea Res. 42, 641-673 (1995)

\section{Acknowledgements}

This research was financially supported by the French INSU/LEFE - CHICO (2013-2016) project, the Swedish Research Council (VR-349-2012-6278) and the Swiss National Science Foundation (grants PP00P2-144811 and PP00P2_172915 to S.L.J). The research has been conducted within the framework of the international IMAGES program and the MD159 PACHIDERME/IMAGES cruise, with technical support from the Institute Paul Emile Victor (IPEV). We express our thanks to G. Isgüder that assisted in foraminifera picking.

\section{Author contributions}

All authors contributed extensively to this work. S.D.-A. prepared the manuscript and collected the organic and inorganic carbon data together with the coccolith data. Coccolith abundance and mass collection, using the SYRACO software, would not have been possible without L.B. and Y.G. E.M. and G.S. provided the XRF and foraminifera data E.M., S.L.J., and G.S. particularly contributed to the redaction of the article.

\section{Additional information}

Supplementary Information accompanies this paper at https://doi.org/10.1038/s41467 018-04625-7.

Competing interests: The authors declare no competing interests.

Reprints and permission information is available online at http://npg.nature.com/ reprintsandpermissions/ 
Publisher's note: Springer Nature remains neutral with regard to jurisdictional claims in published maps and institutional affiliations.

(c) (i) Open Access This article is licensed under a Creative Commons Attribution 4.0 International License, which permits use, sharing, adaptation, distribution and reproduction in any medium or format, as long as you give appropriate credit to the original author(s) and the source, provide a link to the Creative Commons license, and indicate if changes were made. The images or other third party material in this article are included in the article's Creative Commons license, unless indicated otherwise in a credit line to the material. If material is not included in the article's Creative Commons license and your intended use is not permitted by statutory regulation or exceeds the permitted use, you will need to obtain permission directly from the copyright holder. To view a copy of this license, visit http://creativecommons.org/ licenses/by/4.0/.

(C) The Author(s) 2018 